\title{
Model Pembelajaran Teknik Dasar Passing Sepakbola untuk Sekolah Menengah Pertama
}

\section{Learning Model Basic Passing Technique of Football for Junior High School}

\author{
Papat Yunisal \\ STKIP Pasundan, Cimahi, Jawa Barat, Indonesia \\ Papat_yunisal@yahoo.com
}

\begin{abstract}
Abstrak
Tujuan penelitian ini adalah untuk membuat model pembelajaran teknik dasar passing sepakbola untuk sekolah menengah pertama di Kota Bandung. Prosedur penelitian dan pengembangan yang digunakan adalah model Borg dan Gall yang terdiri sepuluh langkah yaitu: Penelitian dan pengumpulan informasi, Perencanaan, Pengembangan awal produk, Uji lapangan, Revisi produk utama, Uji coba lapangan utama, Revisi produk operasional, Uji lapangan operasional, Revisi produk akhir, Diseminasi dan implementasi. Model pembelajaran Teknik dasar passing sepakbola yang dikembangkan ada 24 model passing, dimana 24 model tersebut dapat digunakan untuk pembelajaran passing sepakbola untuk siswa sekolah menengah pertama. Produk model pembelajaran teknik dasar passing sepakbola sangat efektif dan efisien untuk dilakukan pada siswa sekolah menengah pertama.
\end{abstract}

Kata kunci: Pengembangan, model pembelajaran, passing, sepakbola

\begin{abstract}
The purpose of this study was to create a learning model of basic football passing techniques for junior high schools in the city of Bandung. The research and development procedure used is the Borg and Gall model which consists of ten steps, namely: Research and information collection, Planning, Product early development, Field testing, Main product revision, Main field trial, Operational product revision, Operational field test, Product revision end, Dissemination and implementation. The learning model of the basic football passing technique that was developed was 20 passing models, of which 20 models could be used for soccer passing learning for junior high school students. The product of the basic passing soccer learning model is very effective and efficient to do for junior high school students.
\end{abstract}

Keywords: Development, learning model, passing, football. 


\section{PENDAHULUAN}

Pendidikan jasmani merupakan media untuk mendorong pertumbuhan fisik, perkembangan psikis, keterampilan motorik, pengetahuan dan penalaran, penghayatan nilai-nilai: sikap, mental, emosional, sportivitas, dan sosial, serta pembiasaan pola hidup sehat yang bermuara untuk merangsang pertumbuhan dan perkembangan kualitas fisik dan psikis yang seimbang (Hughson \& Tapsell, 2012; Lynch \& Soukup, 2016; Sallis \& McKenzie, 2013).

Pendidikan jasmani sendiri adalah bagian integral dari pendidikan secara keseluruhan, bertujuan untuk mengembangkan aspek kebugaran jasmani, keterampilan gerak, keterampilan berpikir kritis, keterampilan sosial, penalaran, stabilitas emosional, tindakan moral, aspek pola hidup yang sehat dan pengenalan lingkungan bersih melalui aktivitas jasmani, olahraga dan kesehatan terpilih yang direncanakan secara sistematis dalam rangka mencapai tujuan pendidikan nasional (Malobulu, et al, 2011; Sudjana, 2010).

Adapun yang menjadi salah satu tujuan utama pendidikan jasmani adalah untuk membantu siswa mengembangkan potensi dan bakat yang dimiliki dengan berbagai permainan, hidup sehat dan memiliki kebugaran jasmani, melalui berbagai aktivitas fisik yang diharapkan agar mampu meningkatkan kapasitas belajar, meningkatkan ketahanan tubuh terhadap penyakit, dan menurunkan angka tidak masuk ke sekolah (Lutan, et al, 2002), serta siswa mampu belajar keterampilan berolahraga. Dengan demikian pendidikan jasmani sebagai satu sumber untuk meningkatkan potensi dan bakat siswa di sekolah. Dalam upaya untuk meningkatkan potensi dan bakat yang dimiliki dapat dilakukan dengan berbagai aktifitas fisik seperti permainan, aktivitas air, atletik dan pembentukan karakter melalui beladiri pencak silat, hal ini dapat dilakukan sebagai identifikasi dasar untuk membantu dan mengarahkan potensi dan bakat siswa menuju lebih baik dari perkembangan motorik maupun karakter.

Namun, berdasarkan pengamatan peneliti dilapangan bahwa guru dalam memberikan pembelajaran salah satu permainan bola besar yaitu sepak bola guru cenderung menyampaikan materi secara langsung seperti mengumpan, menendang, menahan bola dan menggelola bola (dribling) tanpa melalui tahapan-tahapan dan langkah-langkah yang sederhana atau mudah, sehingga inti dari pembelajaran penguasaan teknik dasar tidak diperoleh. Hal ini akan berdampak terhadap penggalian potensi dan bakat yang dimiliki siswa tidak tersalurkan, sehingga apa yang diharapan dalam proses pembelajaran tidak terwujud.

Hasil observasi dan wawancara pada guru-guru pendidikan jasmani terkait dengan pemebelajaran sepak bola, kebanyakan siswa dalam mengikuti pembelajaran tidak optimal dalam melakukan berbagai aktivitas permainan seperti passing, menendang dan dribling, hal ini banyak faktor yang mempengaruhi apakah karena tidak menggunakan media yang tidak tepat atau 
pendekatan/motode yang diberikan membuat siswa bosan, sehingga akan mengendurkan semangat atau motivasi tidak sungguh-sungguh dalam menerima materi.

Berdasarkan hasil analisis studi pendahuluan yang telah dipaparkan, dan melihat berbagai kesenjangan di atas, berkaitan dengan sistem pembelajaran di sekolah menengah pertama diperlukan sebuah pengembangan pembelajaran pendidikan jasmani sebagai solusi yang mampu mengatasi berbagai permasalahan tersebut. Oleh karena itu, penelitian ini mencoba untuk menyajikan sebuah model pembelajaran pendidikan jasmani dengan pendekatan sirkuit belajar gerak berbasis pembelajaran drill yang diharapkan dapat diaplikasikan di sekolah menengah pertama sesuai dengan amanat pendidikan nasional. Penelitian ini juga ingin melihat sebarapa jauh model pembelajaran pendidikan jasmani diharapakan dapat meningkatkan kebugaran jasmani siswa.

\section{Metode Penelitian}

Penelitian ini dilaksanakan di sekolah - sekolah menengah pertama di Kota Bandung yang tersebar pada 10 sekolah menengah pertama. Seluruh siswa dipilih secara acak sehingga diperoleh 88 orang siswa yang dijadikan subjek penelitian.

Sementara untuk metode penelitian yang digunakan dalam penelitian ini adalah metode penelitian dan pengembangan (Research and Development). Langkah-langkah penelitian dan pengembangan oleh Borg and Gall (1989) digambarkan sebagai berikut:

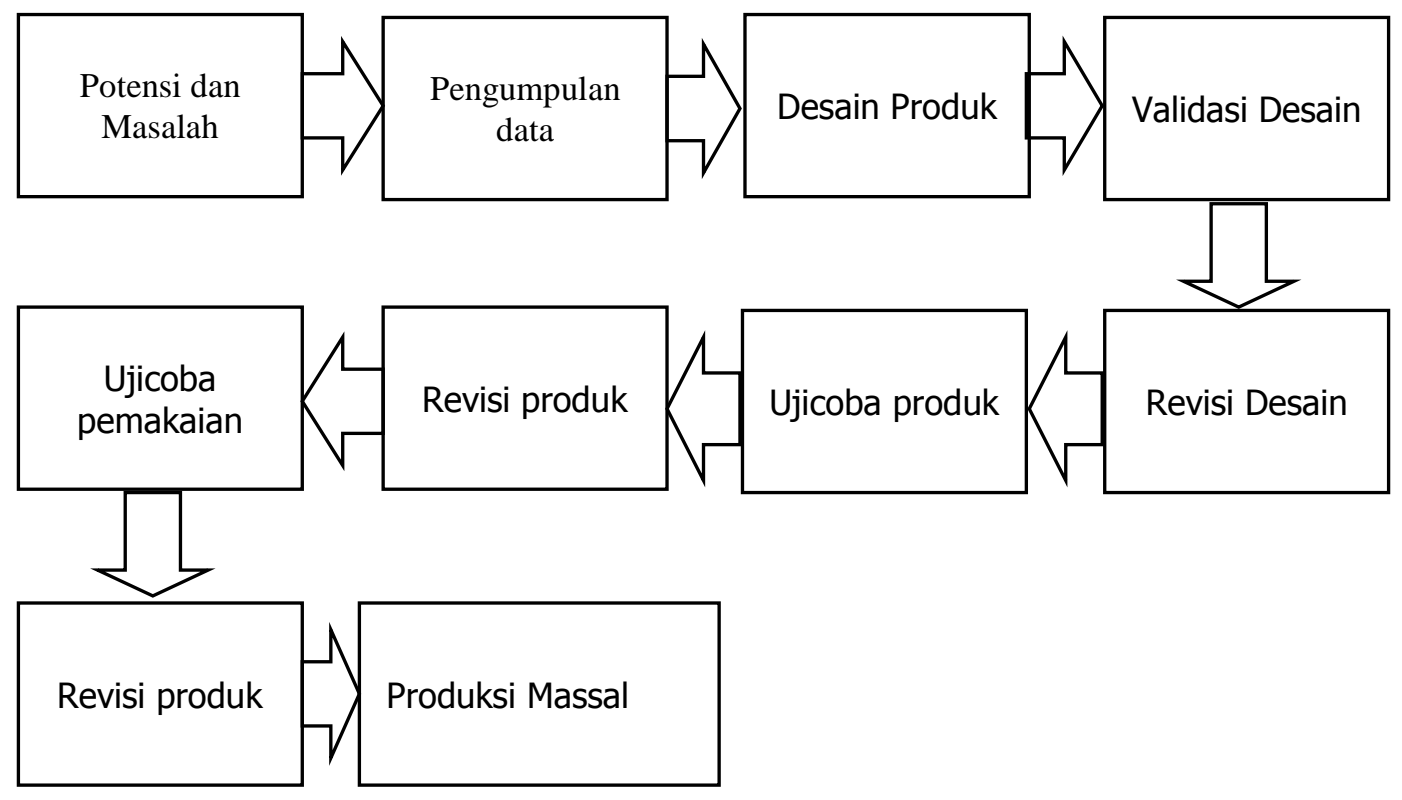

Gambar 1

Langkah-langkah penggunaan Metode Research and Development (R\&D) 


\section{HASIL DAN PEMBAHASAN}

Hasil

Data studi pendahuluan yang diperoleh dari hasil studi kepustakaan disajikan dan disertai dengan analisis kebutuhan melalui pengamatan lapangan yang dilaksanakan ketika berlangsungnya kegiatan pembelajaran disekolah. Data validasi ahli diperoleh melalui angket dari tiga orang ahli pelatih sepakbola, dua orang ahli media pembelajaran, dan tiga orang guru pendidkan jasmani. Data uji coba dari siswa SMP dikumpulkan dengan menggunakan instrumen angket. Uji coba diadakan dua kali, yaitu (1) Uji coba kelompok kecil sebanyak 23 siswa SMP, dan (2) Uji coba kelompok besar lebih (lapangan yang lebih luas) sebanyak 65 siswa SMP di Kota Bandung. Siswa SMP yang digunakan dalam uji coba, diambil secara acak sederhana. Justru pada penelitian ini peneliti ingin mengetahui dampak dari penggunaan produk seperti yang dilakukan oleh Borg and Gall, maka perlu dibentuk dua kelompok, yaitu kelompok eksperimen model latihan transisi dan kelompok kontrol, supaya dapat dilakukan uji perbedaan dengan $t$-test.

Teknik yang digunakan untuk mengolah data hasil penelitian dari ahli guru pendidikan jasmani dan pelatih sepak bola , dan siswa SMP sebagai subjek dari uji coba dengan menggunakan teknik persentase. Tabel lima berikut menyajikan data hasil studi pendahuluan, data validasi dari tiga orang guru pendidikan jasmani dan pelatih sepakbola , serta uji coba kelompok kecil, dan uji coba kelompok besar (lapangan lebih besar), dan uji pelaksanaan lapangan serta draf model final.

Setelah melalui proses observasi dan desain produk yang akan diberikan, selanjutnya produk ini divalidasi oleh beberapa para ahli dalam hal ini pelatih sepak bola diperoleh hasil (91.48\%) untuk keterampilan passing dari control dan penguasaan bola (81.49\%), sehingga model pembelajaran keterampilan passing dasar bermain sepakbola ini sangat layak untuk digunakan. Serta pelatih tersebut memberikan masukan agar organisasi latihan pada model keterampilan passing berbasisi bermain sepakbola ini perlu memperhatikan jumlah kelompok menjadi lebih banyak, menambah beberapa aturan permainan supaya tujuan latihan untuk meningkatkan keterampilan transisi sesuai dengan harapan yang diinginkan, serta variasi latihan yang peneliti rancang sebanyak 45 item ini harus lebih disederhanakan lagi.

Selanjutnya setelah divalidasi oleh para ahli dan produk model pembelajaran teknik passing ini direvisi adalah menguji cobakan produk terhadap kelompok kecil dan kelompok besar. Dari uji coba kelompok kecil dan kelompok besar diperoleh hasil $(75.14 \%)$ dan $(81,13)$ yang berarti model pembelajaran keterampilan dasar bermain sepakbola ini layak dipakai. Namun meskipun sudah dikatakan layak, tetap terdapat masukan dari beberapa para ahli diantaranya seperti diperlukannya tambahan tentang aturan permainan. 
Setelah dilakukan serangkaian uji coba dan revisi serta penyempurnaan terhadap draf model, maka tersusunlah model pembelajaran passing berbasis transisi permainan sepakbola untuk siswa SMP Sepakbola yang terdiri dari 12 bentuk variasi model latihan transisi dari bertahan menjadi menyerang dan 12 bentuk variasi model latihan transisi dari menyerang ke bertahan. Jadi total jumlah variasi model yang disajikan dalam penelitian ini adalah sebanyak 24 variasi model. Model penemuan ini peneliti beri nama Alex's Transition Model.

\section{Pembahasan}

Berdasarkan hasil uji coba kelompok kecil dan kelompok besar serta uji efektivitas model, diketahui bahwa produk model pembelajaran passing berbasis transisi permainan sepakbola yang dikembangkan dalam penelitian ini (Alex's Transition Model) dianggap memenuhi persyaratan untuk disosialisasikan dan diterapkan dalam pembelajaran sepakbola di sekolah menengah pertama dan bahkan layak dijadikan sebagai salah satu model latihan keterampilan bermain sepakbola, khususnya keterampilan passing berbasis fase transisi pada siswa PPLP Sepakbola.

Selanjutnya dalam pasal pembahasan ini dikemukakan empat penjelasan, yaitu 1) Keunggulan model, 2) Kelemahan model, 3) Faktor pendukung model, dan 4) Faktor penghambat model.

\section{$>\quad$ Keunggulan Model}

Adapun kelebihan produk model pembelajaran passing berbasis transisi permainan sepakbola ini terlihat dengan adanya buku panduan berupa produk akhir dan media latihan keterampilan sepakbola, fokus pada fase transisi. Kedua bentuk keunggulan ini tentu sangat bermanfaat bagi para guru di sekolah maupun pelatih PPLP Sepakbola sebagai panduan dan pedoman dalam menjalankan proses pembelajaran dan latihan demi untuk meningkatkan efektivitas kinerjanya.

Apabila buku panduan dan media produk model pembelajaran passing berbasis transisi permainan sepakbola ini diamati serta dipahami sebelum maupun sesudah proses pembelajaran ataupun latihan tentu prosesnya akan dapat berjalan dengan mudah, lancar, efektif dan efisien.

\section{$>\quad$ Kelemahan Model}

Kelemahan produk model pembelajaran passing berbasis transisi permainan sepakbola (Alex's Transition Model) ini dalam kuantitas pembelajaran maupun latihannya, yang hanya menampilkan beberapa variasi keterampilan transisi dalam bermain sepakbola dan belum seluruhnya. Sedangkan apabila dilihat dalam segi prestasi, seorang pemain sepakbola yang baik itu harus menguasai berbagai teknik passing dan prinsip transisi, seperti: transisi dari bertahan ke menyerang, menyerang ke bertahan, individual transisi, transisi group dan transisi tim. Bila para 
pemain sepakbola tidak menguasai berbagai keterampilan bermain sepakbola termasuk bermacammacam prinsip transisi jangan harap mereka bisa berprestasi tinggi dalam membela klub ataupun bermain di level tim nasional.

\section{$>\quad$ Faktor Pendukung Model}

Hasil penelitian ini berupa produk, yaitu model latihan passing berbasis transisi bermain sepakbola. Kegunaannya tentu untuk diterapkan ketika pembelajaran ataupun latihan keterampilan bermain sepakbola diberbagai sekolah menengah pertama, sekolah sepakbola atau klub-klub. Sehubungan dengan adanya berbagai bentuk kegiatan pertandingan sepakbola pada tingkat daerah sampai tingkat internasional, maka frekuensi latihan dan intensitas latihan berbagai sekolah sepakbola dan klub-klub perlu ditingkatkan. Hal ini secara tidak langsung menjadi motivasi dan faktor pendukung penulis untuk menciptakan model ini (Alex's Transition Model).

Adapun beberapa kegiatan atau lembaga yang secara tidak langsung dapat menerapkan model ini yaitu: (1) seluruh sekolah menengah tingkat pertama, dalam proses pembelajaran passing dalam materi sepakbola (2) Kalender kompetisi AFC setiap tahun untuk mempersiapkan Timnas U19 (yang dilaksanakan satu kali dalam dua tahun). Adanya pembentukan Timnas U-19 sebagai pemicu dalam meningkatkan target latihan bagi siswa PPLP Sepakbola, agar para siswanya bisa terpilih menjadi pemain nasional nantinya. (3) PPLP Sepakbola menerima siswa baru setiap tahun. Pada umumnya target anak-anak muda usia ini dalam berlatih sepakbola agar dapat kelak menjadi pemain andalan di daerahnya. Berdasarkan data yang diperoleh bahwa kebanyakan pemain yang bermain di level atas, (apakah itu Liga Super maupun Divisi Utama) berasal dari tamatan PPLP Sepakbola. Timnas pelajar Indonesia juga berasal dari pemain PPLP Sepakbola. (4) Liga Pedidikan Indonesia, kegiatan ini juga menjadi pilihan pemain agar bisa bermain sampai ke tingkat Nasional. Bila mereka bisa menembus level nasional kemungkinan besar mereka akan terpilih untuk mengikuti lipio camp pemilihan pemain yang akan diberangkatkan ke beberapa klub eropa sebagai program puncak dari LPI ini. (5) Banyaknya terdapat sekolah-sekolah sepakbola dan klub-klub yang belum melaksanakan latihan secara baik dan mencapai hasil yang maksimal, menjadi penyemangat penulis untuk menciptakan suatu model latihan keterampilan bermain sepakbola khususnya pada fase transisi .

\section{$>\quad$ Faktor Penghambat Model}

Penerapan produk model pembelajaran passing berbasis transisi permainan sepakbola ini belum dapat berjalan dengan sempurna. Beberapa faktor penghambat antara lain: (1) Terbatasnya jumlah pelatih yang memiliki lisensi melatih yang memadai untuk melatih di tingkat PPLP Sepakbola se-Indonesia. Berdasarkan referensi yang penulis peroleh semestinya pelatih PPLP Sepakbola minimal memiliki lisensi 'B' baik level nasional maupun level Internasonal (AFC/FIFA) 
- (2) Sarana dan prasarana latihan yang ada kurang memadai dan tidak tersedia dengan lengkap seperti bola, rompi, cones, marka, portable goal serta lapangan yang tidak terawat. (3) Masih ada beberapa PPLP sepakbola di Indonesia yang belum memiliki lapangan sendiri untuk berlatih.

\section{KESIMPULAN}

Berdasarkan hasil analisis penelitian, penulis menyimpulkan bahwa produk model pembelajaran passing berbasis transisi permainan sepakbola yang dikembangkan ini:

Efektif, maksudnya adalah model ini setelah diterapkan sesuai dengan situasi bermain sepakbola yang sebenarnya (Like Games Like Match).

$>$ Efisien, model ini disusun berdasarkan prinsip-prinsip yang ada dalam fase-fase transisi dalam permainan sepakbola.

$>$ Bermafaat, karena model ini bisa menjadi referensi bagi para guru SMP dan pelatih PPLP Sepakbola maupun para siswanya dalam menjalankan proses pembelajaran maupun latihan.

$>$ Model ini sangat sederhana dan mudah dipahami, serta diterapkan dari sisi variasi, kesesuaian, dan manfaat dari pembelajaran maupun latihan itu sendiri.

Model ini dikemas sangat menarik berbentuk sebuah buku dan dilengkapi dengan media latihan sehingga memudahkan para pelatih dan siswa dalam memahami materi latihan serta meningkatkan efektivitas proses latihan yang sedang berlangsung.

\section{DAFTAR PUSTAKA}

Borg, W.R \& Gall M.D (1989), Education Research an Introduction. New York: Longman.

Hughson, J., \& Tapsell, C. (2012). Physical Education and the “Two Cultures ” Debate: Lessons from Dr . Leavis. Quest. https://doi.org/10.1080/00336297.2006.10491891

Lutan, Rusli, et al. (2002). Pendidikan Kebugaran Jasmani: Orientasi Pembinaan di Sepanjang Hayat Jakarta: Depdiknas-Ditjora. h. 9.

Lynch, T., \& Soukup, G. J. (2016). "Physical education ”, “ health and physical education ”, “ physical literacy " and " health literacy ": Global nomenclature confusion. Cogent Education, 1-22. https://doi.org/10.1080/2331186X.2016.1217820

Malobulu, Syarifudin., et al. (2011). Olahraga dan Pendidikan Jasmani dalam Wajah Keutuhan NKRI. Jakarta: PT. Ardadizya Jaya, h. 124.

Sallis, J. F., \& McKenzie, T. L. (2013). Physical Education's Role in Public Health. Research 
Quarterly for Exercise and Sport. https://doi.org/10.1080/02701367.1991.10608701

Sudjana, Nana. (2010). Dasar-Dasar Proses Belajar Mengajar. Bandung: Sinar Baru Algesindo. h. 49-54. 